Wydziat Studiów Edukacyjnych

Uniwersytet im. Adama Mickiewicza

\title{
Działania z zakresu ratownictwa społecznego w Polsce w latach 1944-1948
}

\begin{abstract}
Social response in Poland in the years 1944-1948
The article concerns the field of social care and social assistance in the first years of the People's Republic of Poland provided to individuals who suffered distress during World War Two. The timeline of the paper covers the years 1944-1948. At that time, the focus of social care and social assistance was satisfying the fundamental needs of the people, in particular in environments affected by the destruction of war. It included, among others, ensuring food, health care, accommodation, education and employment. The scale of the relief provided after the war by various Polish and international institutions was unprecedented in the history of the Polish social service with one in four Poles involved i.e. over 6 million people in total.
\end{abstract}

Keywords: human services, relief provided after the war, social assistance, social care

W pierwszych latach Polski Ludowej działania z zakresu opieki i pomocy społecznej miały charakter ratownictwa społecznego - pomocy doraźnej dla osób, które ucierpiały na skutek wojny. Okres ratownictwa społecznego rozpoczął się po zakończeniu działań wojennych i trwał do roku $1948^{1}$. Warto w tym miejscu doprecyzować, że metodyka pracy socjalnej wyróżnia dwa etapy pomocy w katastrofach: interwencję natychmiastową oraz długofalową ${ }^{2}$. Zatem lata powojennej akcji ratowniczej były zasadniczo już drugim etapem pomocy ofiarom wojny (wobec pierwszego etapu prowadzonego w czasie wojny m.in. przez Radę Główną Opiekuńczą ${ }^{3}$. Opieka i pomoc społeczna w tym czasie była

1 Wśród autorów opracowań jako data graniczna okresu ratownictwa funkcjonuje również rok 1947. Zakończenie działań wojennych, w zależności od terenów Rzeczpospolitej, nastąpiło już w roku 1944, stąd mniej zasadne wydaje się mówienie o ,zakończeniu II wojny światowej”.

2 J. Szmagalski, Praca socjalna w sytuacjach katastrof $i$ klęsk, „Praca Socjalna” 1997/1, s. 37.

3 Zob. B. Kroll, Rada Główna Opiekuńcza, Warszawa 1985. 
skoncentrowana na zaspokajaniu podstawowych potrzeb ludności, szczególnie w środowiskach dotkniętych zniszczeniami wojennymi ${ }^{4}$. Obejmowała ona m.in. zapewnienie: żywności, ochrony zdrowia, mieszkania, oświaty oraz miejsca pracy ${ }^{5}$. Skala pomocy doraźnej udzielanej po zakończeniu wojny była niespotykana w dziejach polskich służb społecznych i objęła co czwartego Polaka, czyli łącznie ponad $6 \mathrm{mln}$ osób ${ }^{6}$.

Działalność ratownicza miała zróżnicowany charakter na terenie ziem polskich, stopniowo wyzwalanych spod okupacji hitlerowskiej. Działania Rady Głównej Opiekuńczej były zastępowane bądź uzupełniane przez odradzające się organizacje społeczne i opiekuńcze już od 1944 r., kiedy to wyzwalano ziemie polskie na wschód od Wisły?

Jednym z pierwszych elementów akcji ratowniczej była pomoc ludności, którą wojna pozbawiła dachu nad głową. Sytuacja mieszkaniowa w pierwszych latach po wojnie była szczególnie ciężka, zwłaszcza w miastach, które uległy zniszczeniu. W Warszawie, najbardziej zniszczonym w czasie wojny mieście Europy ${ }^{8}$, duża część ludności żyła w przeludnionych mieszkaniach (z metrażu kilkunastu metrów kwadratowych korzystało 10-15 osób). Do zamieszkania wykorzystywano piwnice spalonych domów, przeciekające strychy itp. Działalność opieki społecznej polegała na pomocy materialnej, niewielkiemu wsparciu w remontach oraz na doprowadzeniu dzieci do szkół (dzięki tej formie pomocy około 95\% mogło uczęszczać na zajęcia) ${ }^{9}$.

Działań ratowniczych wymagały także tereny wiejskie. Wykorzystując naturalne możliwości wsi, starano się zaspokoić potrzeby najuboższych wprowadzając ustawowo zasadę pomocy wzajemnej. Po zakończeniu działań wojennych wiele gospodarstw rolnych na ziemiach polskich było dotkniętych niedostatkiem inwentarza żywego, narzędzi, zwierząt (liczba koni zmniejszyła się o 60\%) oraz rąk do pracy, a część obszarów działań wojennych była wyludniona, bądź nie była jeszcze rozminowana. Niepełne wykonanie zasiewu jesienią 1944 r., mogące skutkować brakiem żywności, musiało zostać uzupełnione wiosną. Próbując zaradzić tym problemom Minister Rolnictwa i Reform Rolnych,

${ }^{4}$ K. Wódz, Stużby społeczne w Polsce. Geneza, kierunki rozwoju, metody pracy, Katowice 1982, s. 28.

5 Poradnik Pracownika Socjalnego, pod red. J. Rosnera, wyd. III zm., Warszawa 1973, s. 20.

${ }^{6}$ Z. Czyżowska, Świadczenia socjalne w czterdziestoleciu PRL, Warszawa 1987, s. 108; M. Karczewski, Opieka społeczna, w: Polityka społeczna, pod red. A. Rajkiewicza, Warszawa 1979, s. 501.

7 W. Pawłowska, Po roku 1945, w: Opieka społeczna w Warszawie 1923-1947, pod red. M. Gładkowskiej $\mathrm{i}$ in., Warszawa 1995, s. 71.

${ }^{8}$ Po przeprowadzeniu remontów nadawało się do użytku 59\% budynków na Pradze, 15 w śródmieściu, $37 \%$ w dzielnicy północnej, 41\% w dzielnicy południowej, 17\% w dzielnicy zachodniej. Po wyzwoleniu stolicy nie funkcjonowały wodociągi i kanalizacja, a doprowadzana elektryczność wystarczała do oświetlenia kilkunastu domów. Postępująca odbudowa nie zaspokajała potrzeb mieszkańców, choćby z powodu tempa w jakim zwiększała się ich liczba: z 1,3 mln mieszkańców Warszawy w momencie wyzwolenia, tj. styczniu 1945 pozostało 130 tys., w marcu było już 350 tys., a w maju ponad 400 tys. osób. Zob. Przemówienie prezydenta m. st. Warszawy Tołwińskiego w dn. 5 maja 1945 w czasie VII sesji KRN, w: Sprawozdanie Stenograficzne z posiedzeń Krajowej Rady Narodowej w dn. 3, 4 i 5 maja 1945, Warszawa 1945, sz. 242-243.

9 L. Franciszkiewicz, Przystosowanie polityki opiekuńczej do wymagań normalizującego się życia spotecznego, „Opiekun Społeczny” 1948/5-6, s. 191-192. 
Edward Bertold podpisał Rozporządzenie o obowiązku sąsiedzkiej pomocy wzajemnej ${ }^{10}$, w myśl którego właściciele gospodarstw mieli pomóc w uprawie roli sąsiadom zaraz po zakończeniu robót na swoich gruntach, względnie zająć się jednocześnie zarówno swoim, jak i sąsiedzkim polem i inwentarzem. Pierwszeństwo do otrzymania pomocy miały rodziny, w których były osoby walczące w czasie wojny z Niemcami, czynni żołnierze, osoby wywiezione przez okupanta do obozów oraz wzięci do niewoli ${ }^{11}$. Nadzór nad wykonaniem rozporządzenia, którego zasadniczym celem było efektywne przeprowadzenie kampanii siewnej wiosną, minister powierzył władzom lokalnym: wójtom i starostom, działającymi w porozumieniu $\mathrm{z}$ gminnymi i powiatowymi radami narodowymi oraz Związkiem Samopomocy Chłopskiej. W omawianym rozporządzeniu żadna pomoc ze strony władz centralnych nie była przewidziana, choć wyraźnie wspominał o niej jeszcze na początku 1945 r. Prezes Rady Ministrów E. Osóbka Morawski ${ }^{12}$. Ostatecznie część akcji siewnej wykonało wojsko (głównie na Ziemiach Odzyskanych) ${ }^{13}$, wsparcia udzielił również Związek Radziecki14. Wobec powtórzenia się problemów w obsianiu pól w kolejnym roku, podobne do wspomnianego rozporządzenie podpisał rok później Minister Rolnictwa i Reform Rolnych - Stanisław Mikołajczyk ${ }^{15}$.

Zadania Caritas, posiadającej rozbudowane struktury w całej Polsce, w pierwszych latach po wojnie wyznaczyły potrzeby ludności, wymagającej przede wszystkim pomocy doraźnej. Polegała ona na prowadzeniu ponad pół tysiąca placówek, zajmujących się m.in. dożywianiem ludności (kuchnie ludowe - często darmowe, ale też tzw. tanie kuchnie dla emerytów i słabo zarabiających), izb dworcowych (dla podróżnych, uchodźców, przesiedleńców, bezdomnych itp.), stacji opieki nad matką i dzieckiem, domów noclegowych (dla przesiedleńców i powracających do swoich domów, z ograniczonym do 3 dni czasem pobytu) ${ }^{16}$. Na terenach, gdzie kościelne instytucje charytatywne ze względów organizacyjnych nie mogły się odrodzić bądź rozpocząć działalności, Kościół przyłączał

${ }^{10}$ Rozporządzenie Ministra Rolnictwa i Reform Rolnych z dnia 11 kwietnia 1945 r. o obowiązku sąsiedzkiej pomocy wzajemnej w gospodarstwach rolnych na rok 1945, Dz.U. 1945 nr 15 poz. 87.

${ }^{11} \mathrm{~W}$ rozporządzeniu jest mowa jedynie o walkach z Niemcami oraz o niewoli niemieckiej.

12 E. Osóbka-Morawski mówił o udzieleniu pomocy w ziarnie i udostępnieniu maszyn rolniczych rolnikom, a nawet o pomocy dla mieszkańców miast chcących uprawiać działki ogrodniczo-warzywne, Zob. Przemówienie E. Osóbki-Morawskiego w czasie VI sesji KRN w dn. 2 stycznia 1945, w: Sprawozdanie stenograficzne z posiedzeń Krajowej Rady Narodowej w dn. 31 grudnia 1944 oraz $2 i 3$ stycznia 1945 r., Warszawa 1946, s. 82 .

13 Zob. Sprawozdanie Komisji Wojskowej o wniosku w sprawie udziału Wojska Polskiego w akcji żniwnej (poset E.L. Odorkiewicz), w: Sprawozdanie Stenograficzne z posiedzeń Krajowej Rady Narodowej w dn. 20, 21, 22 i 23 września 1946, Warszawa 1946, 1. 384-386.

${ }^{14}$ Przemówienie Prezesa Rady Ministrów E. Osóbki-Morawskiego w dn. 3 maja 1945 w czasie VII sesji KRN, w: Sprawozdanie Stenograficzne z posiedzeń Krajowej Rady Narodowej w dn. 3, 4 i 5 maja 1945, Warszawa 1945, s. 26.

15 Rozporządzenie Ministra Rolnictwa i Reform Rolnych z dnia 19 lipca 1946 r. o obowiązku sąsiedzkiej pomocy wzajemnej w gospodarstwach rolnych, Dz.U. $1946 \mathrm{nr} 35$ poz. 222. Zob. Referat Ministra Rolnictwa i reform Ronych o akcji siewnej, w: Sprawozdanie Stenograficzne z posiedzeń Krajowej Rady Narodowej $w$ dn. 29, 30, 31 grudnia 1945 oraz w dn. 2 i 3 stycznia 1946 r., Warszawa 1946, 1. 225-231.

${ }^{16}$ D. Zamiatała, Caritas..., s. 192-201, S. Jasiński, O dziełach miłosierdzia, „Caritas” 1946/4, s. 7-12. 
się do działań świeckich organizacji humanitarnych przez bezpośrednią pomoc, bądź przeznaczanie części ofiar $\mathrm{z}$ tacy ${ }^{17}$.

Akcja ratownicza obejmowała również pomoc dla ocalałych Żydów. Początek organizowania przez Żydów podmiotów zajmujących się niesieniem powojennej pomocy związany jest z powstaniem w wyzwolonym Lublinie Polskiego Komitetu Wyzwolenia Narodowego. Przy Komitecie utworzono samodzielny Referat do spraw Pomocy Ludności Żydowskiej kierowany przez mjr. dr. Sz. Herszerhorna, który niósł pomoc Żydom wychodzącym z kryjówek, bądź przekradających się przez linię frontu, a także dzieciom ocalonym z obozu zagłady na Majdanku. Wobec rozległego wymiaru potrzeb w lipcu 1944 powstał Komitet Żydowski, mający usprawnić pomoc i uaktywnić samopomoc. Odradzające się partie żydowskie, m.in. Bund, Poalej Syjon, Ichud doprowadziły do przekształcenia Komitetu Żydowskiego w październiku 1944 r. w organizację polityczną o nazwie Centralny Komitet Żydów Polskich, która po miesiącu zmieniła nazwę na Centralny Komitet Żydów w Polsce (posługujący się skrótem CKŻP). CKŻP rozpoczął tworzenie struktur terenowych, a jego działalność obejmowała wszystkie dziedziny odradzającej się społeczności żydowskiej. Działaniami ratowniczymi i pomocowymi zajmowano się głównie w ramach Wydziału Opieki Społecznej (dystrybucja paczek żywnościowych i ubrań, przydzielanie zapomóg żywnościowych i stypendiów, pomoc Polakom pomagającym Żydom w czasie okupacji ${ }^{18}$ ). Ponadto Wydział Ewidencyjny rejestrował ocalonych, prowadził poszukiwanie rodzin, odtwarzał dokumenty osobiste, Wydział Prawny miał w swoim zakresie obowiązków takie działania, jak: pomoc prawna przy rewindykacji majątków, odzyskiwanie ukrywanych dzieci, dokumentowanie przypadków kolaboracji, kompletowanie zeznań świadków w procesach zbrodniarzy wojennych, pomoc prawna dla osób będących w konflikcie z prawem, opieka nad więźniami, natomiast Wydział Opieki nad Dzieckiem organizował domy dziecka, bursy, sanatoria, kolonie letnie i kluby sportowe ${ }^{19}$. Na płaszczyźnie ideologicznej organizacja opowiadała się jednoznacznie za narzuconą Polsce władzą „ludową”, przy jednoczesnym oskarżaniu rządu londyńskiego o współudział w holokauście ${ }^{20}$. Obok CKŻP działały także kongregacje religijne, często będące do niej w opozycji, które oprócz organizowania życia religijnego zajmowały się opieką społeczną i oświatą ${ }^{21}$.

\footnotetext{
17 R. Węsierski, Caritas czy humanitaryzm, „Caritas” 1945/1-2, s. 10.

${ }_{18}$ Pomoc tę prowadzono wspólnie z Wydziałem Prawnym do roku 1948, kiedy to powstała Komisja Pomocy Polakom.

19 A. Cała, Centralny Komitet Żydów w Polsce, w: A. Cała, H. Węgrzynek, G. Zalewska, Historia i kultura Żydów Polskich. Stownik, Warszawa 2000, s. 42-44.

${ }^{20}$ Zob. J. Żaryn, Hierarchia Kościoła katolickiego wobec relacji polsko-żydowskich w latach 1945-1947, w: Wokół pogromu kieleckiego, Warszawa 2006, s. 110.

${ }^{21}$ A. Cała, Centralny Komitet Żydów w Polsce..., s. 43.
} 


\section{Pomoc dla ludności przesiedlanej i repatriowanej}

Perspektywa nieuchronności powojennych ruchów ludnościowych była obecna w świadomości międzynarodowej niemalże od początku wojny. Już sześć tygodni po jej rozpoczęciu Franklin Delano Roosevelt na forum Międzynarodowego Komitetu do Spraw Uchodźców Politycznych stwierdził: kiedy ta upiorna wojna się skończy, może być nie jeden milion, ale 10 lub 20 milionów mężczyzn, kobiet i dzieci, które wkroczą na szeroka arenę, jaka stanowi problem uchodźców ${ }^{22}$. Od tego czasu organizacje międzynarodowe rozpoczęły przygotowania do przeprowadzenia repatriacji.

Przygotowania polskich władz na uchodźctwie do działań repatriacyjnych również rozpoczęły się dość wcześnie. Pierwszy dokument dotyczący akcji powojennych przemieszczeń ludności na ziemiach polskich przygotowało Ministerstwo Pracy i Opieki Społecznej rządu londyńskiego w 1943 r. Zakładano w nim podporządkowanie akcji Centralnemu Międzynarodowemu Biurze Repatriacyjnemu, natomiast na poziomie organizowanych w Polsce lokalnych ośrodków dla repatriantów planowało się, oprócz czynności urzędowych (weryfikacji narodowości i wystawienia dokumentów), także opiekę sanitarną, pomoc żywnościową i ubraniową ${ }^{23}$. Kolejne lata przygotowań rządu londyńskiego na forum międzynarodowym do powojennej repatriacji Polaków przebywających poza Ojczyzną okazały się daremne, gdyż prosowieckie władze w Polsce, które rozpoczęły rządy w 1944 roku nie były zainteresowane ich kontynuowaniem, ani nawet zapoznaniem się z nimi. Jak zwraca uwagę Krystyna Kersten: ośrodki polityczne w kraju, które powołały KRN, a następnie weszły w skład PKWN i Rzadu Tymczasowego, nie dysponowały informacjami dotyczacymi polskiego wychodźstwa po 1939 r. Orientowały się też bardzo słabo $w$ działaniach przygotowujacych repatriacje $i$ pozbawione byty kontaktów z organizacjami międzynarodowymi. [...] organizacja repatriacji przez władze, która zamierzała budować Polskę na nowych podstawach ustrojowych, właśnie zaczynata się od próżni ${ }^{24}$. Przejęcie roli koordynatora akcji repatriacyjnej przez PKWN, a później przez Rząd Tymczasowy spowodowało, że wielu polityków opowiadających się za rządem londyńskim było jej przeciwnych ${ }^{25}$.

Przeprowadzenie akcji przesiedleńczo-repatriacyjnej dla ogromnej, co najmniej dziewięciomilionowej, rzeszy ludności było niewątpliwym wyzwaniem dla nowo utworzonych władz państwowych. Powojenne ruchy ludnościowe dotyczyły przesiedlenia Polaków zza Buga; wysiedlenia ludności ukraińskiej, ruskiej, białoruskiej, litewskiej i obywateli ZSRR; wysiedlenia Niemców (zwłaszcza z tzw. Ziem Odzyskanych); przesiedlenia ludności z województw centralnych na tzw. Ziemie Odzyskane; przesiedlenia

22 F. D. Roosevelt, Address to the Intergovernmental Committee on Political Refugees, October 17, 1939, „Department of State Bulletin” t. I, nr 17, 21 X 1939; cyt. za: K. Kersten, Repatriacja ludności polskiej po II wojnie światowej. Studium historyczne, Wrocław 1974, s. 67.

${ }^{23}$ K. Kersten, Repatriacja ludności polskiej po II wojnie światowej. Studium historyczne, Wrocław 1974, s. 72 .

24 Ibidem, s. 90.

${ }^{25}$ Zob. ibidem, s. 170 n. 
ludności polskiej i narodów zza wschodniej granicy w związku z delimitacją granicy pomiędzy Polską a ZSRR (w 1946 i 1948 r.); przesiedlenie Ukraińców w ramach akcji „Wisła”. Ponadto miała miejsce repatriacja i reemigracja Polaków (zarówno uchodźców, jak i więźniów) z terenów ZSRR, Niemiec, Czechosłowacji, Francji i innych krajów, wśród których znalazła się nawet odległa Mandżuria, z której powróciły 784 osoby, zamieszkujące tam w okresie międzywojennym ${ }^{26}$.

W celu koordynowania akcją repatriacyjną i przesiedleńczą, dekretem PKWN z 7 października 1944, powołano Państwowy Urząd Repatriacyjny, a jego pierwszym dyrektorem został Władysław Wolski. Najważniejszym zadaniem PUR było sprawne przeprowadzenie akcji przemieszczenia kilku milionów ludności, a jednym z obowiązków było zapewnienie opieki sanitarnej i żywnościowej ${ }^{27}$. Pomocą rzeszom potrzebujących zajmowały się również inne organizacje. Chcąc usprawnić akcję pomocy dla powracających z Niemiec, Ministerstwo Administracji Publicznej wydało 30 czerwca 1945 r. Okólnik nr 22, w którym całkowitą odpowiedzialność za repatriację z Zachodu przekazało Państwowemu Urzędowi Repatriacyjnemu. Przejściowa pomoc miała być udzielana przez władze bezpieczeństwa, wojsko, sanitariuszy, lekarzy oraz organizacje zajmujące się niesieniem pomocy. Dotychczasowa pomoc, niesiona przez Centralny Komitet Opieki Społecznej (CKOS), PCK i inne instytucje miała być kontynuowana, ale już pod egidą PUR $^{28}$.

Repatrianci i przesiedleńcy pokonywali drogę, przechodząc do kolejnych punktów etapowych, rozsianych gęsto po całym kraju, głównie w miejscowościach posiadających stacje kolejowe, w których otrzymywali niezbędną pomoc. Największe znaczenie dla władz miały punkty wlotowe, czyli pierwsze, z jakimi spotykali się przybysze. Miały one robić dobre wrażenie, stąd dbano, by posiadały napisy powitalne, wydawano w nich

${ }^{26}$ Problematyka powojennej repatriacji jest opracowana w publikacji D. Suli Działalność przesiedleńczorepatriacyjna Państwowego Urzędu Repatriacyjnego w latach 1944-1951, Lublin 2002; zob. też: S. Banasiak, Działalność osadnicza Państwowego Urzędu Repatriacyjnego na ziemiach odzyskanych w latach 1945-1947, Poznań 1963; K. Kersten, Repatriacja ludności polskiej po II wojnie światowej, Wrocław 1974; W. Gieszczyński, Państwowy Urzad Repatriacyjny w osadnictwie na Warmii i Mazurach (1945-1950), Olsztyn 1999; W. Pogorzelski, Stużba Zdrowia Państwowego Urzędu Repatriacyjnego (1945-1948), Łódź 1948.

${ }^{27}$ Dekret Polskiego Komitetu Wyzwolenia Narodowego z dnia 7 października 1944 r. o utworzeniu Państwowego Urzędu Repatriacyjnego, Dz.U. 1944 nr 7 poz. 32 wymienia następujący zakres działania PUR:

a) organizacja repatriacji ludności z obszarów innych państwa na terytorium Państwa Polskiego.

b) regulowanie planowego napływu repatriantów,

c) opieka sanitarno-żywnościowa podczas przeprowadzania repatriacji,

d) planowe rozmieszczenie repatriantów i organizacji ich osadnictwa na ziemiach polskich,

e) prowadzenie akcji pomocy repatriantom w zakresie gospodarczej odbudowy warsztatów pracy,

f) popieranie zrzeszeń i instytucyj społecznych w kraju i zagranicą, o ile ich celem jest niesienie pomocy i opieka nad repatriantami.

Pół roku później do kompetencji PUR dodano także organizowanie przesiedleń ludności polskiej na tzW. Ziemie Odzyskane; zob. Dekret z dnia 7 maja 1945 r. o częściowej zmianie dekretu Polskiego Komitetu Wyzwolenia Narodowego z dnia 7 października 1944 r. o utworzeniu Państwowego Urzędu Repatriacyjnego, Dz.U. 1944 nr 7 poz. 32.

Wiosną 1945 znaczenie PUR zostało ograniczone jedynie do organizowania transportu migrantów na terenie kraju i opieki nad nimi.

${ }^{28}$ Okólnik nr 22 Ministra Administracji Publicznej z dn. 30 czerwca 1945, Nr dz. I Og.9347/45, Archiwum Akt Nowych (AAN), Centralny Komitet Opieki Społecznej (CKOS), sygn. 112, k.617-618. 
gorące posiłki oraz kawę. Z kolei niechęć ludzi budziły ścisłe kontrole i wykonywane im zdjęcia. Wzorcowe punkty, które były najczęściej obecne w prasie, miały swoje siedziby w Dziedzicach, Szczecinie i Międzylesiu ${ }^{29}$.

Z racji dużej liczby ludności przepływającej przez tak zorganizowany system pomocy (np. w Poznaniu na przełomie maja i czerwca 1945 r. rejestrowano ok. 10 tys. osób dziennie, a w lipcu 1945 na punkcie przeładunkowym w Mikulczycach rejestrowano 3-4 tys. osób) pojawiały się trudności przejawiające się w braku funduszy, odpowiednich pomieszczeń, lekarzy i lekarstw, żywności i inne ${ }^{30}$ Szczególnie trudną sytuację miały osoby wracające ze Wschodu. Problemy, jakie dotykały wycieńczoną ludność to rabunki mienia, korupcja (np. kolejarzy, zbierających na każdym postoju łapówkę w zamian za ruszenie), awantury i rozboje wywołane przez żołnierzy sowieckich. Często podróżowano w odkrytych wagonach razem z bydłem, bez możliwości umycia się, a czas oczekiwania na kolejny pociąg w punkcie przelotowym wydłużał się nieraz nawet do dwóch tygodni. Z drugiej strony w najlepszej sytuacji były osoby wracające z amerykańskiej strefy okupacyjnej Niemiec, które wyjeżdżając, były dobrze zaopatrywane przez UNRRA i po przybyciu do Dziedzic trafiali również do placówki UNRRA, która zaopatrywała ich w żywność na okres dwóch miesięcy ${ }^{31}$.

W celu skoordynowania pomocy dla byłych więźniów obozów koncentracyjnych i obozów pracy, w lutym 1945 r. powstała Międzyministerialna Komisja Opieki nad Zwolnionymi z Obozów Hitlerowskich ${ }^{32}$. Komisja miała za zadanie współdziałać z MPiOS w pomocy wszystkim osobom wracającym z Niemiec (z wyraźnym wykluczeniem obywateli tego kraju), a więc byłym więźniom obozów koncentracyjnych i obozów pracy, jeńcom wojennym oraz tzw. pozostałym ofiarom wojny. Działaniami kierowały 3 duże organizacje społeczne: Centralny Komitet Opieki Społecznej (CKOS), Polski Czerwony Krzyż (PCK) oraz Centralny Komitet Żydów w Polsce (CKŻP). PCK prowadził tzw. czołówki, zorganizowane możliwie blisko linii frontu, do których należała ewidencja, zapewnienie pierwszej pomocy, ewentualne odesłanie do szpitala, wyżywienie oraz zorganizowanie transportu do jednego z punktów zbornych, organizowanych przez CKOS w większych miastach Polski. W punktach zbornych uzupełniano ewidencję o relacje dotyczące zbrodni niemieckich oraz udzielano podstawowych informacji. Udzielano tam pomocy w postaci żywności (w formie kuchni dietetycznych dla osób wracających z obozów), odzieży i noclegu. Była przy nich również czynna sekcja sanitarna PCK. Z punktów zbornych kierowano do domów rodzinnych, bądź w przypadku mieszkańców terenów wschodnich, które nie weszły w skład powojennej Polski, do nowych miejsc osiedlenia. Osoby wymagające opieki wysyłano do szpitali, zakładów opiekuńczych, sanatoriów, domów wypoczynkowych itp. Jeńców przekazywano Armii Czerwonej lub

\footnotetext{
29 D. Sula, Działalność przesiedleńczo-repatriacyjna..., s. 41.

${ }^{30}$ Protokół z posiedzenia w sprawie pomocy dla powracających z Niemiec z dnia 2 czerwca 1945, AAN, CKOS, sygn. 112, k. 581-583.

31 D. Sula, Działalność przesiedleńczo-repatriacyjna..., s. 39-44.

32 Opieka Spoleczna 1944-1947, Wydawnictwo MPiOS, [1948], AAN, MPiOS, sygn. 2/402/0/263, s. 15.
} 
Armii Polskiej. Dla obcokrajowców organizowano oddzielne punkty zborne, z których pomagano przedostać się do ojczyzny. Żydzi byli kierowani do CKPZ ${ }^{33}$.

Wraz ze zmianą granic pojawiła się konieczność przesiedlenia pensjonariuszy zakładów opiekuńczych zza Buga. O skali akcji, którą przeprowadzano od wiosny 1946 r. świadczą dane liczbowe: z samego tylko Lwowa w 1946 r. przeniesiono zakłady z 3 tys. pensjonariuszy, natomiast z Wilna 2 tys. matek z dziećmi. MPiOS przygotowało sieć placówek, mieszczących się na ogół w budynkach zakładów opiekuńczych poniemieckich, w ówczesnym województwie dolnośląskim (większość) oraz zachodniopomorskim, pomorskim, gdańskim i mazurskim, w których Państwowy Urząd Repatriacyjny miał umieścić przesiedleńców. W większości placówek nie było personelu, w części był tylko kierownik lub administracja, jedynie w niektórych był personel - świecki, bądź zakon$n^{34}$. W tym samym czasie wysiedlano niemieckie zakłady opiekuńcze z Ziem Odzyskanych, z których pensjonariusze i personel mogli zabrać najwyżej część wyposażenia (przesiedlane zakłady zza Buga przyjeżdżały bez wyposażenia rzeczowego) ${ }^{35}$.

Wśród podróżujących w okresie powojennym, kiedy ruch na dworcach kolejowych był wzmożony, było wiele kobiet ciężarnych oraz matek z małymi dziećmi. Formą pomocy dla nich były całodobowe Izby Dworcowe dla Matki i Dziecka organizowane na większych, zwłaszcza węzłowych stacjach kolejowych, których celem było ułatwienie podróży w przypadku wielogodzinnego oczekiwania na przesiadkę (zakładano, że w można w nich przebywać do 24 godzin) oraz zapewnienie biletu na dalszą podróż. Izby składały się na ogół z sali noclegowej dla dzieci i stołówki. Usługi w nich świadczone były na ogół bezpłatne (czasami było trzeba dopłacić za posiłek). W skład personelu wchodziły pielęgniarki, opiekunki społeczne i sprzątaczki. Izby podlegały Ministerstwu Pracy i Opieki Społecznej, natomiast organizacjami, które je prowadziły były głównie: Liga Kobiet, Caritas i PCK. Likwidacja Izb rozpoczęła się latem 1948 r. (działało ich wówczas 64) i była spowodowana usprawnieniem komunikacji kolejowej oraz stabilizacją życia powojennego ${ }^{36}$.

Wydaje się być konieczne poruszenie kwestii zarobków pracowników PUR, z uwagi na podobieństwo niskiego uposażenia pracowników opieki społecznej występujące w kolejnych dziesięcioleciach. Wynagrodzenie pracowników PUR było nawet kilkukrotnie niższe od urzędników ${ }^{37}$ i miało tendencje spadkowe. Niewielkie premie nie były wypła-

33 Uchwała Rady Ministrów Rządu Tymczasowego RP w przedmiocie opieki nad powracającymi z obozów hitlerowskich, 26 maja 1945, AAN, CKOS, sygn. 112, k. 563-564; Pismo MKOZOH do Rady Ministrów [brak daty], AAN, CKOS, sygn. 112, k. 570-573; Organizacja akcji przyjmowania przybywających z obozów hitlerowskich, AAN, CKOS, sygn. 112, k. 575-578.

34 Korespondencja PUR z MPiOS, AAN, MPiOS 392, k. 37n

35 Pisma Naczelnika Wydziału Nadzoru i Polityki Opiekuńczej M. Rakowskiego z marca 1946, AAN, MPiOS 392, s. 47n.

${ }^{36}$ Notatki, regulaminy, korespondencja dot. Izb Dworcowych, w: Organizowanie Izb Dworcowych, AAN, MPiOS, sygn. 275.

${ }^{37}$ Dane z października 1946 mówią o zarobkach od 1200 do 3500 zł dla pracowników PUR oraz zarobkach rozpoczynających się od 6000 dla pracowników Izby Skarbowej w Szczecinie. Zob. D. Sula, Działalność przesiedleńczo-repatriacyjna..., s. 38. 
cane regularnie, a nieprzyznawanie ich było spowodowane np. brakiem udziału w pochodzie pierwszomajowym. Ponadto od 1946 r. cofnięto deputaty żywnościowe oraz przydziały z UNRRA, mimo że pracownicy innych urzędów i instytucji je otrzymywali. Do pracy nie motywowało również poczucie tymczasowości etatu, który straci rację bytu po zakończeniu akcji repatriacyjno-przesiedleńczej, a także działania członków PPR i PPS, którzy doszukiwali się konspirantów wrogich Polsce Ludowej wśród pracowników PUR $^{38}$.

\section{Pomoc dla dzieci - ofiar wojny}

Niecierpiącą zwłoki była konieczność zapewnienia opieki ogromnej liczbie dzieci w tym wielu sierotom, które wskutek działań wojennych nie miały zapewnionych właściwych warunków życia. Niedożywienie i wycieńczenie organizmów powodowały wysoką zachorowalność i umieralność na gruźlicę, stąd organizując opiekę, starano się w pierwszej kolejności zapewnić ją właśnie dzieciom oraz kobietom ciężarnym ${ }^{39}$.

Wskutek wojny wiele rodzin zostało rozbitych - dzieci odłączone od rodziców przebywały poza terenem Polski (głównie w Niemczech i ZSRR), bądź też to rodzice byli nieobecni z powodu śmierci lub uwięzienia, przebywania w miejscu pracy przymusowej, pozostawania w niewoli. Wpływ wojny na najmłodszych członków narodu ilustrują dane statystyczne - odsetek dzieci wśród ogółu mieszkańców spadł z 42\% w 1939 r. do 33 w $1947^{40}$. Jednym z poważniejszych zadań służb zajmujących się wówczas opieką i pomocą społeczną była akcja łączenia rodzin oraz umożliwianie im normalnego funkcjonowania $^{41}$.

Pomimo podejmowanych wysiłków, znaczącym problemem powojennej Polski stało się sieroctwo. Spis szkolny z 1945 r. wykazał, że wśród 7 mln dzieci jest aż 22\% osamotnionych (czyli ponad 1,5 mln) ${ }^{42}$, z czego ok. 140 tys. to sieroty całkowite. Jedną z form opieki nad sierotami było wysyłanie ich poza zniszczone wojną tereny do placówek opiekuńczych i rodzin zastępczych. Dotyczyło to w największym stopniu dzieci z Warszawy, gdzie praktyka ta obecna była do końca lat $50 .{ }^{43}$ Oficjalne dane mówią o 73 tys. dzieci,

38 Ibidem, s.36-39.

39 Zob. J. Rutkiewicz, Opieka nad dzieckiem i matka w stolicy, „Opiekun Społeczny” 1946/3-4, s. 6-11.

40 Opieka Spoleczna 1944-1947..., s. 59.

${ }^{41}$ Cz. Kępski, Idea miłosierdzia a dobroczynność i opieka, Lublin 2003, s. 127.

42 A. Kelm, Opieka nad dziećmi i młodzieża w Polce Ludowej, „Kwartalnik Pedagogiczny” 1964/3, s. 96. Taką samą liczbę znajdziemy w opracowaniu Opieka Społeczna 1944-1947..., s 59. Niższą liczbę - 1,1 mln podał Minister Pracy i Opieki Społecznej, Jan Stańczyk w liście z 9 kwietnia 1946, skierowanym do Katarzyny Kozik, Prezeski Generalnej Stowarzyszenia Matek Żołnierza w związku z sesją Rady UNRRA w Atlantic City w 1946r, (AAN, MPiOS, sygn. 100, s. 5-6). Również inne liczby (300 tys. sierot i 1,5 mln półsierot) podała członkini zarządu głównego Społeczno-Obywatelskiej Ligi Kobiet Stanisława Garncarczykowa w przemówieniu na forum KRN 30 grudnia 1945, zob. Sprawozdanie Stenograficzne z posiedzeń Krajowej Rady Narodowej $w$ dn. 29, 30 i 31 grudnia 1945 r. oraz $w$ dn. 2 i 3 stycznia 1946, Warszawa 1946, 1. 157.

${ }^{43}$ A. Kelm, Formy opieki nad dzieckiem w Polsce Ludowej, Warszawa 1983, s. 89. 
które do 1947 r. znalazło opiekę w rodzinach zastępczych, ponadto prowadzono akcję przekazywania najmłodszych dzieci z domów dziecka do rodzin ${ }^{44}$.

Władze państwowe nie w pełni radziły sobie z tak dużą liczbą dzieci wymagających opieki. Stanisława Garncarczykowa w czasie obrad KRN w grudniu 1945 mówiła o braku odpowiednich działań państwa wobec problemu osieroconych, które w praktyce bardzo często zmuszone są głodować, żebrać oraz zajmować się handlem, przez co skazane są na wykolejenie społeczne. Brak zainteresowania władz dziećmi (jak twierdziła) skutkuje częstymi przypadkami śmierci. Szczególnie ciężka sytuacja panowała na wsi, gdzie przebywało 80\% dzieci: w biednej rodzinie wiejskiej dziecko nie zna cukru, nie zna tluszczu i prawie również nie zna mleka. Tysiace rodzin chłopskich mieszka w bunkrach i ziemiankach. [...] Gospodarstwa bez koni, bez krów, to dzisiaj na wsi nie rzadkość [...]. Dzieci nie maja odzieży i obuwia, nie moga więc uczęszczać do szkoty ${ }^{45}$.

Specyficznej opieki wymagały dzieci, które w czasie wojny były objęte akcją germanizacyjną, zwłaszcza tych spośród około 200 tys. ${ }^{46}$, którym udało się wrócić do kraju. Los dzieci polskich nie był jednakowy, część z nich pracowała przymusowo w obozach dla małoletnich, niektóre dziewczęta kierowano do pracy jako pracownice domowe, inne umieszczano w zakładach, lub oddawano do rodzin niemieckich. Spośród dzieci, które udało się odzyskać, te najmłodsze oraz przebywające w rodzinach zastępczych, prawie nie mówiły po polsku, a niektóre na pytanie o narodowość odpowiadały „Ich bin Deut-

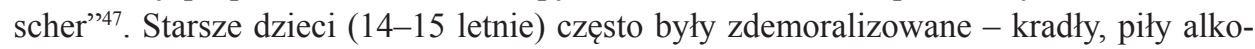
hol, uciekały z ośrodków, były nosicielami chorób wenerycznych, zdarzały się dziewczęta w trakcie lub po odbytej ciąży, albo takie które poroniły, a także dzieci z niepełnosprawnością ${ }^{48}$. Dzieci wracające z Niemiec trafiały wpierw do ośrodków repatriacyjno-opiekuńczych, gdzie były ewidencjonowane i badane przez lekarzy, a następnie oczekiwały na odbiór przez rodzinę, bądź trafiały do ośrodków. Także wobec dzieci osieroconych w wyniku działań wojennych, zamieszkujących Ziemie Odzyskane, była prowadzona polonizacja ${ }^{49}$. W akcję ewidencji zaginionych dzieci w celu ułatwienia poszukiwań włączyło się wiele organizacji, w tym Kościół - w marcu 1948 r. ówczesny biskup lubelski Stefan Wyszyński apelował do księży swojej diecezji o wzywanie parafian do kancelarii parafialnych i zbieranie danych osobowych dzieci wywiezionych do Niemiec,

44 Opieka Spoleczna 1944-1947..., s. 61.

45 Sprawozdanie Stenograficzne z posiedzeń Krajowej Rady Narodowej w dn. 29, 30 i 31 grudnia 1945 r. oraz $w$ dn. 2 i 3 stycznia 1946, Warszawa 1946, ł. 157-158.

${ }^{46}$ Taką liczbę zaginionych posiadało PCK i podaje ją w piśmie z 18 marca 1949 skierowanym do Generalnego Pełnomocnika Rządu do Spraw Repatriacji, AAN, MPiOS, sygn. 373, k. 251.

47 J. Sadulska, Moja praca wychowawcza w Lubece, s. 24, Maszynopis ze zbiorów Państwowego Muzeum na Majdanku, sygn. VII-810, cyt za: Źródła do pedagogiki społecznej, tom II, pod red. I. Lepalczyk, Warszawa 1988, s. 483; Germanizacja, deportacja i eksterminacja dzieci polskich [część większego opracowania pozbawionego strony tytułowej, brak autora], AAN, MPiOS, sygn. 373, k. 153-155.

48 J. Jedrzejowska, Pismo do Gabinetu Ministra Pracy i Opieki Społecznej z dn. 24 kwietnia 1948, AAN, MPiOS, sygn. 373, k. 91; J. Marosz, M. Wodzinowska, Sprawozdanie z pobytu w Okręgu Śląko-Dąbrowskim PCK $w$ Katowicach, 1948, AAN, MPiOS, sygn. 373, k. 119-129.

49 Źródła do pedagogiki społecznej, t. II, pod red. I. Lepalczyk, Warszawa 1988, s. 483. 
aby przyczynić się do odzyskania dziatwy polskiej, skazanej na germanizację, a może i na utratę wiary świętej ${ }^{50}$.

Wśród organizacji, które odegrały największą rolę w prowadzeniu akcji ratowniczej były Caritas, Chłopskie Towarzystwo Przyjaciół Dzieci, Robotnicze Towarzystwo Przyjaciół Dzieci, Polski Czerwony Krzyż i Centralny Komitet Żydów w Polsce. Szczególną opieką zostały otoczone dzieci i młodzież. W sprawozdaniach tych organizacji z lat powojennych wyraźnie widać, że częstym przypadkiem była współpraca w udzielaniu pomocy.

Caritas zajmowała się zapewnieniem opieki nad dziećmi w zakładach opieki całkowitej, częściowej, prowadzeniem dożywiania w szkołach na terenach zniszczonych wojną, misjami (izbami) dworcowymi, opieki nad matką i dzieckiem oraz półkolonii. Organizacja ta zajęła się również akcją umieszczania sierot $\mathrm{w}$ rodzinach, starając się otoczyć opieką także rodziny przyjmujące ${ }^{51}$.

Wśród największych organizacji społecznych, niosącą pomoc dzieciom był także Polski Czerwony Krzyż. W 1946 r. z ramienia tej organizacji działało 21 sierocińców, 2 bursy, była także prowadzona akcja dożywiania dla 700 dzieci. W 56 kuchniach wydawano 100 tysięcy posiłków miesięcznie, ponadto dostarczano pokarm na tereny wiejskie, położone z dala od miast, dostarczając odzież dla dzieci, puszki kariolu, butelki tranu, puszki nutryny oraz mleko skondensowane w ramach akcji dożywiania dzieci „Kropla mleka”. W wakacje niektóre dzieci miały możliwość wyjechania na kolonie, do sanatoriów, prewentoriów gruźliczych. Wśród innych krajów, z których organizacje Czerwonego Krzyża włączyły się w akcję pomocy, były m.in. Szwajcaria, Stany Zjednoczone, Dania, Bułgaria, Szwecja ${ }^{52}$. PCK prowadził także Stacje Opieki nad Matką i Dzieckiem, punkty sanitarno-odżywcze, punkty lekarskie, które zapewniały opiekę matkom repatriantkom oraz żonom i niemowlętom po poległych i zaginionych wojskowych. Ponadto prowadził kilkadziesiąt stołówek zapewniających całodzienne wyżywienie dla 2 tys. dzieci, świetlice oraz półkolonie. PCK był również odpowiedzialny za zapewnienie opieki 15 tys. dzieci przesiedlanych z ZSRR wiosną $1946 \mathrm{r}^{53}$.

Reaktywowane w 1944 r. w Lublinie Robotnicze Towarzystwo Przyjaciół Dzieci w pierwszych latach działalność skupiło się na udzielaniu doraźnej pomocy dzieciom ofiarom wojny, priorytetowo traktując dzieci pozbawione rodziny ${ }^{54}$. Także Chłopskie Towarzystwo Przyjaciół Dzieci (powstałe w styczniu 1946 r.) niosło pomoc doraźną najmłodszym. Towarzystwo uruchamiało punkty sanitarne, obsługujące kilkadziesiąt tysięcy dzieci z gmin wiejskich, do których nie docierała inna pomoc. Oprócz dożywiania

50 S. Wyszyński, W sprawie wywiezionych podczas wojny dzieci Zamojszczyzny, „Wiadomości Diecezjalne Lubelskie" 1948/3, s. 111.

51 J. Majka, Sprawozdanie, plany, potrzeby Organizacji Caritas w akcji opiekuńczej nad dzieckiem i młodzieża, 1946, AAN, MPiOS, sygn. 251, k. 93-94.

${ }^{52}$ H. D., Polski Czerwony Krzyż w trosce o dziecko, „Opiekun Społeczny” 1946/5-6, s. 59-60.

${ }^{53}$ H. Lenk, Sprawozdanie z działalności PCK w zakresie opieki nad dzieckiem dla Podkomitetu Pomocy Dzieciom i Młodzieży z 6 marca 1946, AAN, MPiOS, sygn. 251, k. 95.

${ }^{54}$ M. Balcerek, Historyczny rozwój tendencji wychowawczych TPD, w: Pedagogika Towarzystwa Przyjaciół Dzieci, red. B. Butrymowicz, L. Gomółka, s. 41-42. 
i pierwszej pomocy sanitarnej, na dużą skalę przeprowadzano odwszawianie i odświerzbianie ludności ${ }^{55}$.

Centralny Wydział Opieki nad Dzieckiem przy Centralny Komitet Żydów w Polsce roztaczał opiekę nad ocalałymi dziećmi żydowskimi, których całkowitą liczbę szacowano w 1946 r. na 6 tys. Z uwagi na bardzo ciężką sytuację tych dzieci, które najczęściej były osierocone, bądź ich rodziny nie miały środków do życia, pomoc im udzielana miała bardzo często charakter opieki całkowitej w zakładach zamkniętych. Ponadto organizowano opiekę półotwartą oraz otwartą w formie zasiłków, stypendiów, żywności ${ }^{56}$.

\section{Dzialalność organizacji spoza Polski}

Istotnym elementem opieki i pomocy społecznej tego okresu była pomoc z zagranicy. Miała ona formę wsparcia udzielanego przez rządy wielu krajów, a także z zagranicznych towarzystw charytatywnych.

Wśród organizacji międzynarodowych niosących pomoc Polakom w latach powojennych była się m.in. United Nations Relief and Rehabilitation Administration (UNRRA) - Administracja Narodów Zjednoczonych do spraw Pomocy i Odbudowy, utworzona w 1943, z inicjatywy USA (głównego świadczeniodawcy), Wielkiej Brytanii, ZSRR i Chin. Jej celem była pomoc krajom najbardziej poszkodowanym przez wojnę. Organizację powołało Zgromadzenie Ogólne Narodów Zjednoczonych, a jej pomysłodawcą i zarazem pierwszą osobą pełniącą funkcję prezesa był Polak, Ludwik Rajchman, młodszy brat Heleny Radlińskiej.

Akcja UNRRA rozpoczęła się w Polsce pod koniec czerwca 1945 i obejmowała różne formy pomocy (dane do grudnia 1946):

- zaopatrywanie ludności w odzież (także obuwie, koce, kołdry itp.) - UNRRA przekazała ponad 13 tys. ton tego rodzaju darów,

- żywność (5500 ton), przy rozdziale żywności obowiązywała zasada pierwszeństwa do jej dostępu dla zakładów opiekuńczych, kuchni powszechnych, a następnie dla matek z dziećmi, repatriantów i osób dotkniętych klęskami żywiołowymi,

- 8,2 tony nasion oraz 5 sztuk traktorów przekazano ośrodkom rolnym MPiOS,

- 75 wagonów sprzętu kuchennego (pochodzącego m.in. z demobilu armii amerykańskiej), przeznaczonego dla wyposażenia kuchni powszechnych oraz dla wyposażenia zakładów opiekuńczych,

- maszyny do szycia (144 szt.), narzędzia szewskie (476 zespołów) - wyposażono nimi zakłady szkoleniowe.

\footnotetext{
${ }_{5}$ Plan pracy Chłopskiego Towarzystwa Przyjaciót Dzieci $w$ zakresie opieki nad dziećmi na terenach zniszczonych, 1946, AAN, MPiOS, sygn. 251, k. 96-97.

${ }^{56}$ Sprawozdanie z działalności Centralnego Wydziału Opieki nad Dzieckiem przy CKŻP, 1946, AAN, MPiOS, sygn. 251, k. 98-100.
} 
- mydło i zabawki - przekazane zostały zakładom opiekuńczym ${ }^{57}$.

Dary te były rozdysponowywane m.in. przez organa Ministerstwa Pracy i Opieki Społecznej, PUR, Ministerstwo Oświaty, Ministerstwo Zdrowia.

Wartość materialna darów od organizacji zagranicznych, nie wliczając w to kosztów pracy osób zatrudnionych przy ich organizowaniu i rozdawaniu, wyniosła w roku 1946 prawie $37 \mathrm{mln}$ dolarów ${ }^{58}$.

W ramach pomocy UNRRA dla Polski w 1945 r. dostarczono 315 tys. ton towarów: żywności (prawie połowa z tej sumy), ubrań i tekstyliów oraz leków, a także sprzęt potrzebny do odbudowy przemysłu (500 ciężarówek, 11 lokomotyw, sprzęt telefoniczny i górniczy), sprzęt rolniczy (3,5 tys. traktorów, nawozy, krowy mleczne, konie, nasiona). Ponadto dostarczony sprzęt sanitarny pozwolił urządzić 241 szpitali $^{59}$.

Rozdawanie darów UNRRA wiązało się czasami z nadużyciami. Bywało, że brak paczek UNRRA, bądź dawanie w zamian za należne pracownikom wynagrodzenie kuponów żywnościowych, stawało się nawet jednym z powodów do strajku ${ }^{60}$. Wydaje się to być zrozumiałe wobec faktu, że wiele akcji strajkowych w pierwszych latach po wojnie (1945-1946) było spowodowanych niedostatkiem żywności. Ponadto przestępstwa w związku z pomocą UNRRA były powodem skierowania w latach 1946-1947 ponad 100 osób do obozu pracy przez Komisję Specjalną do Walki z Nadużyciami i Szkodnictwem Gospodarczym ${ }^{61}$.

Potrzeby, szczególnie w zakresie wyżywienia, powodowały, że rząd polski zabiegał usilnie na arenie międzynarodowej o przedłużenie misji UNRRA przynajmniej na rok $1947^{62}$, co jednak nie nastąpiło, gdyż organizacja zakończyła swą działalność dla Europy 31 grudnia 1946, oddając swoje agendy międzynarodowym organizacjom humanitarnym.

Wartość pomocy UNRRA dla wszystkich krajów wyniosła prawie 3 mld ówczesnych dolarów amerykańskich, przy około dziesięciokrotnie niższej jego wartości niż obecnie. Spośród krajów europejskich największa pomoc, o wartości $481 \mathrm{mln}$ dolarów, trafiła do Polski, ponadto duże wsparcie otrzymały Węgry i Włochy (po $420 \mathrm{mln}$ ), Grecja (350 mln) i Czechosłowacja $(264 \mathrm{mln})^{63}$.

W styczniu 1947, kiedy to swoją misję zakończyła UNRRA, powołano Radę Towarzystw Ochotniczych. W skład Rady wchodziło ponad dwadzieścia podmiotów, z których

${ }^{57}$ Pomoc zagraniczna (materiały Komitetu dla Koordynacji Zagranicznej Akcji Pomocy), AAN, MPiOS, sygn. 251, s. 1-2.

58 Pomoc zagraniczna..., s. 2.

59 Co nam dotychczas dała UNRRA?, „Wola Ludu” 1948/21, s. 2.

${ }^{60}$ Zob. Strajki $w$ Zakładach pracy, sprawozdania, protokoty, zestawienia statystyczne, notatki, korespondencja. 1945-1946, AAN, MPiOS, sygn. 803, s. 1, 2, 83, 161, 185,

${ }^{61}$ Komisja Specjalna do Walki z Nadużyciami i Szkodnictwem Gospodarczym 1945-1954. Wybór dokumentów, oprac. D. Jaroch, T. Wolsza, Warszawa 1995, s. 9.

${ }^{62}$ Uchwała Podkomitetu dla Międzynarodowych Spraw Gospodarczych z dn. 27 lutego 1946 w sprawie wytycznych dla Delegacji na IV Sesję Rady UNRRA w Atlantic City, AAN, MPiOS, sygn. 100, s. 1(92).

${ }^{63}$ A. Garlicki, Pieniądze za kurtyną. Plan Marshalla. Jak 55 lat temu nie weszliśmy do Europy, „Polityka” 2002/22, s. 44-45. 
największą pomoc niosły 2 towarzystwa zza oceanu: Amerykańska Pomoc dla Polski oraz Amerykański Czerwony Krzyż ${ }^{64}$.

Charakterystykę organizacji spoza Polski, które niosły pomoc w czasie usuwania skutków wojny możną prześledzić na podstawie danych z 1946 r. Warta uwagi jest różnorodność udzielanej pomocy. Największą rolę odegrały następujące organizacje:

- American Relief for Poland - Rada Polonii Amerykańskiej, która reprezentowała szereg organizacji społecznych zza oceanu, od końca 1945 r. dostarczała transporty odzieży, obuwia, lekarstw, materiałów sanitarnych, szpitalnych i inne. Przekazywała je ludności, głównie za pomocą dużych organizacji: Caritas, CKOS, YMCA; szacowana wartość rocznej pomocy sięgała blisko $10 \mathrm{mln}$ dolarów ${ }^{65}$;

- Swedish Committee for International Relief - Szwedzki komitet Pomocy Miedzynarodowej, skupiający kilka organizacji współpracujących ze sobą w pomocy dla Polski, którego wartość pomocy wynosiła w skali roku 4,8 mln dolarów, jako jedna z pierwszych organizacji rozpoczął niesienie pomocy już w 1944 r.; prowadził intensywną akcję wyposażania szpitali, a także zakładania nowych placówek - z inicjatywy Szwedów powstały m.in. sanatorium dla dzieci w Otwocku, prewentorium w Dzierżążnie i ośrodek pomocy we Wrzeszczu. Ponadto dostarczał w bardzo dużej ilości środków niezbędnych do opieki nad dzieckiem - mleko w proszku, tran i odzież $\dot{ }^{66}$;

- American Red Cross - Amerykański Czerwony Krzyż, współpracujący bezpośrednio z Polskim Czerwonym Krzyżem, na początku 1946 r. rozpoczął na dużą skalę akcję dostarczania lekarstw, materiałów opatrunkowych, narzędzi chirurgicznych, a także odzieży i żywności; ponadto młodzież Amerykańskiego Czerwonego Krzyża wspomagała polskie dzieci, przesyłając im paczki z przyborami szkolnymi, mydłem i słodycza$\mathrm{mi}^{67}$;

- American Joint Distribution Committee (w skrócie Joint) - Amerykańsko-Żydowski Połączony Komitet Rozdzielczy, którego roczna wartość pomocy wynosiła 3,6 mln dolarów, niósł pomoc przede wszystkim osobom narodowości żydowskiej, sprowadzając do Polski żywność, wyposażenie szpitalne, odzież, obuwie, a także narzędzia i maszyny potrzebne do odbudowy zakładów pracy; Joint współdziałał w ogólnopolskich akcjach pomocy dzieciom oraz udzielał stałej pomocy zakonom, które w czasie wojny ratowały dzieci żydowskie ${ }^{68}$;

- War Relief Services - National Catholic welfare Conference - Pomoc Wojenna Opiekuńcza Organizacja Katolicka za pośrednictwem polskiego Caritasu rozprowadzała

\footnotetext{
${ }^{64}$ Estimated value of programme excluding administrative costs, Działalność zagranicznych towarzystw charytatywnych, AAN, MPiOS, sygn. 501, brak paginacji.

${ }^{65}$ Podane kwoty dotyczą pomocy w roku 1946 i nie obejmują kosztów administracyjnych. Pomoc zagraniczna..., s. 6.

${ }^{66}$ Ibidem, s. 6.

67 Ibidem, S. 5.

68 Ibidem, s. 3.
} 
na terenie całego kraju żywność, odzież i leki; łącznie w 1946 r. dostarczono 4500 ton produktów za 3,6 mln dolarów ${ }^{69}$;

- Don Suisse - Dar Szwajcarii dla ofiar wojny pracował w Polsce od grudnia roku 1945 roku. Organizacja ta udzielała pomocy dzieciom - m.in. zbudowała i prowadziła „Wioskę Dziecięcą” w Otwocku, doposażyła akcję kolonii letnich; ponadto Szwajcarzy pomagali organizować wyposażenie szpitali, dostarczali i rozdzielali odzież, a także narzędzia weterynaryjne; skalę pomocy szacowano na 1,7 mln dolarów;

- Cooperative for American Remittances to Europe (CARE) - Spółdzielnia przesyłek amerykańskich dla Europy sprowadzała do Polski paczki żywnościowe, zakupywane przez osoby prywatne bądź organizacje w Stanach Zjednoczonych i przekazywała bezpośrednio poszczególnym potrzebującym w Polsce, bądź też podmiotom organizującym pomoc i opiekę; w 1946 r. sprowadzono około stu tysięcy paczek za kwotę 1,3 mln dolarów $^{70}$

- International Committee of the Red Cross - Międzynarodowy Komitet Czerwonego Krzyża już we wrześniu 1945 r. rozpoczął przekazywanie za pośrednictwem Joint Relief Commission of the International Red Cross darów organizacji Czerwonego Krzyża wielu krajów z przeznaczeniem dla cywilnych ofiar wojny; wartość pomocy szacowano na 1,2 mln dolarów ${ }^{71}$;

- International Young Men's Christian Association (YMCA) - Międzynarodowy Związek Chrześcijańskiej Młodzieży Męskiej to organizacja ekumeniczna, która przekazywała dostawy za pośrednictwem polskiej YMCA; wkład tej organizacji był szczególnie cenny w czasie akcji pomocy zimowej dożywiania dzieci szkolnych; wartość pomocy sięgała 1,1 mln dolarów ${ }^{72}$.

Oprócz pomocy na dużą skalę wsparcie międzynarodowe przybywało także w mniejszych formach organizacyjnych, np. niektóre organizacje zajmowały się konkretnymi miejscowościami - Anglo-Amerykańska Misja Kwakrów (Anglo-American Quaker Relief Mission) opiekowała się ludnością powiatu kozienickiego; Duński Czerwony Krzyż i Duński Fundusz Pomocy Dzieciom (Danish Red Cross, Danish Save the Children Fund) prowadził akcję dożywiania i udzielał pomocy lekarskiej mieszkańcom Gdańska, Ostródy, Pułtuska, Makowa (woj., warszawskie) i in. ${ }^{73}$; Brytyjski Fundusz Pomocy Dzieciom prowadził akcję dożywiania dzieci w Nieporęcie (woj. warszawskie) i okolicznych wsiach $^{74}$.

Niedostatek zakładów opieki zamkniętej, zwłaszcza dziecięcych, sprzyjał akcji „adoptowania” konkretnych placówek - Polonia Amerykańska wzięła pod opiekę kilka

\footnotetext{
69 Ibidem, S. 4.

70 Ibidem, s. 3.

71 Ibidem, s. 5.

72 Ibidem.

73 Ibidem, S. 4.

${ }^{74}$ Ibidem.
} 
domów dziecka ${ }^{75}$, Ogólna Konferencja Adwentystów Dnia Siódmego (General Conference of Seventh-Day Adventists) udzielała regularnej pomocy Domowi Dziecka w Biel$\mathrm{sku}^{76}$, Pomoc Baptystów dla Polski (Baptist Relief for Poland) opiekowała się domami dziecka w Malborku i Szczytnie ${ }^{77}$. Część organizacji zagranicznych posiadała w Polsce własne placówki, zwłaszcza na terenach dotkliwie zniszczonych, udzielające pomocy żywnościowej (zwłaszcza dożywiania dzieci), odzieżowej i lekarskiej. W placówkach tych pracował wykwalifikowany personel medyczny i pracownicy społeczni ${ }^{78}$.

Organizacje zagraniczne zapewniały także możliwość wyjazdu i odpoczynku poza Polską. Dzieci wysyłano na pobyt do niektórych krajów zachodnich, m.in. Danii, Szwajcarii i Norwegii. Stowarzyszenie World Student Relief oprócz pomocy dla środowiska akademickiego organizowało także wyjazdy zagraniczne dla studentów i profesorów na wypoczynek, leczenie lub studia ${ }^{79}$.

Pomoc przybierała także bardzo indywidualne formy, np. osoby prywatne z Zachodu, mogły wziąć udział w akcji „rodziców chrzestnych” i regularnie przesyłać paczki dla konkretnych dzieci ${ }^{80}$.

Podsumowując akcję ratowniczą w Polsce po zakończeniu działań wojennych, raz jeszcze warto podkreślić ogrom wysiłków władz oraz wielu organizacji społecznych krajowych i zagranicznych, jaki został włożony w pomoc społeczeństwu wycieńczonemu wojną. Niestety doświadczenia organizacyjne oraz mobilizacja i włączenie do niesienia pomocy rzesz wolontariuszy nie zostały po 1948 r. wykorzystane. Narzucony Polsce ustrój socjalistyczny zakładał, że problemy społeczne charakterystyczne dla kapitalizmu przestaną istnieć w ciągu kilku lat, stąd organizacje zajmujące się ich rozwiązywaniem uznano za niepotrzebne i rozpoczęto proces ich likwidacji.

\footnotetext{
75 Kronika, „Dzieci i Wychowawca” 1946/2, s. 45.

76 Pomoc zagraniczna..., s. 5.

77 Ibidem, s. 6-7.

78 Ibidem, s. 2-3.

79 Ibidem, s. 3-4.

80 Ibidem, s. 3.
} 